\title{
Function of Cupric Ion in the Breakage of pBR322 ccc-DNA by D-Glucosamine
}

\author{
Nobuhiro Kashige, Misao KoJima, Yukihiko NaKashima, \\ Kenji WatanABE and Ayako TaChIFUJi* \\ Faculty of Pharmaceutical Sciences and *Faculty of Technology, \\ Department of Civil Engineering, Fukuoka University, \\ Fukuoka 814-01, Japan
}

Received September 18, 1989

\begin{abstract}
The function of $\mathrm{Cu}^{2+}$ in the breakage of $\mathrm{pBR} 322$ ccc-DNA by D-glucosamine was investigated using agarose gel electrophoresis. The maximal stimulatory effects on the DNA breakage and $\cdot \mathrm{OH}$ production were observed at the same concentration of $\mathrm{Cu}^{2+}$ in an aqueous solution of D-glucosamine. An aqueous solution of D-glucosamine containing $1 \mathrm{mM}$ of $\mathrm{Cu}^{2+}$ generated less $\mathrm{O}_{2}^{-}$and $\mathrm{H}_{2} \mathrm{O}_{2}$ than - $\mathrm{OH}$. The generation of these active oxygens, either in the presence or absence of $\mathrm{Cu}^{2+}$, was affected little by the addition of DNA. Superoxide dismutase inhibited the DNA-breaking action of Dglucosamine in the absence, but not the presence, of $\mathrm{Cu}^{2+}$. Hydroxyl radical-scavengers inhibited the reaction in the presence as well as the absence of $\mathrm{Cu}^{2+}$. The reaction in the presence of $\mathrm{Cu}^{2+}$ was inhibited by d-GMP and a different kind of DNA. An atomic absorption analysis showed that copper binding to pBR322 cce-DNA was concentration-dependent. Cupric ions were found to bind to the cecDNA, and were found to stimulate the autoxidation of D-glucosamine via generation of active oxygen molecules, including, especially $\cdot \mathrm{OH}$.
\end{abstract}

In our previous studies, we have found that some aminosugars including D-glucosamine cause the breakage of PL-1 phage ${ }^{1)}$ and pBR322 plasmid ${ }^{2)}$ DNA, and that this reaction is stimulated by $\mathrm{Cu}^{2+}$. In this study, therefore, we have investigated in detail the function of $\mathrm{Cu}^{2+}$ in the breakage of DNA by aminosugars using a system including plasmid pBR322 and D-glucosamine.

\section{Materials and Methods}

Plasmid DNA and other chemicals. Covalently closed, circular duplex DNA (ccc-DNA) of pBR322 and pUC9 were isolated from Escherichia coli W3350/pBR322 and Escherichia coli $\mathrm{C} 600 \mathrm{~S} / \mathrm{pUC} 9$, respectively, as described, in principle, by Kupersztoch-Portony et al. ${ }^{3)}$ Linear DNA of pFP6 was prepared as follows. pBR322 DNA and pUC9 DNA, both digested with EcoRI and Pst I, were ligated using T4 DNA ligase. Competent cells of Escherichia coli $\mathrm{C} 600 \mathrm{~S}$ were transformed with the ligated DNA fragments, and ampicillin resistant-transformants were selected. Then, a transformant containing the 3399 bp plasmid DNA (752 bp fragment of pBR322 plus 2647 . bp fragment of pUC9) was selected. The 3399-bp plasmid
DNA was digested with Bam HI to produce the linear DNA. This DNA, named pFP6 linear DNA, could be clearly distinguished from ccc-, open circular (oc-), and linear DNA of pBR322 by agarose gel electrophoresis.

Nitroblue tetrazolium hydrochloride, 3-[methylthio]propionaldehyde, bovine blood type I superoxide dismutase (3,100 units/mg protein), and bovine liver catalase (3,765 units/mg protein) were purchased from Sigma Chemical. Ethylene (99.5\%) was purchased from Gasukuro-Kogyo Co. The other chemicals and enzymes were purchased from Wako Jun-yaku and Nakarai-Kagaku Co.

Reaction of $p B R 322$ ccc-DNA with D-glucosamine. The reaction mixture $(100 \mu \mathrm{l})$ containing $1 \mu \mathrm{g}$ of pBR322 cccDNA, $0.1 \mathrm{M}$ D-glucosamine, and $50 \mathrm{~mm}$ Tris- $\mathrm{HCl}$ buffer $(\mathrm{pH} 7.2)$ was incubated at $37^{\circ} \mathrm{C}$. At intervals, $10 \mu \mathrm{l}$ of this solution was mixed with $3 \mu$ of a $22.5 \mathrm{~mm}$ EDTA solution (pH 8.2 ) containing $1.5 \%(\mathrm{w} / \mathrm{v})$ sodium dodecyl sulfate, $25 \%(\mathrm{w} / \mathrm{v})$ sucrose and $0.02 \%(\mathrm{w} / \mathrm{v})$ bromophenol blue, and the resultant mixture was electrophoresed on an agarose gel. The electrophoretic procedure and measurement of each DNA (ccc-, oc-, linear-) on the gels were described in our previous paper. ${ }^{2\}}$

Measurement of active oxygen molecules. The superoxide $\left(\mathrm{O}_{2}{ }^{-}\right)$concentration was measured by the method of 
Beauchamp and Fridovich ${ }^{4}$ A mixture of D-glucosamine and $\mathrm{Cu}^{2+}$ was incubated with $10 \mu \mathrm{M}$ nitroblue tetrazolium hydrochloride at $37^{\circ} \mathrm{C}$ in $50 \mathrm{~mm}$ Tris- $\mathrm{HCl}$ buffer $(\mathrm{pH} 7.2)$ containing $0.1 \mathrm{~mm}$ EDTA, and once per minute the OD at $560 \mathrm{~nm}$ of the mixture was measured to obtain the $\triangle \mathrm{OD}_{560 \mathrm{~nm}} / \mathrm{min} \times 100$

The hydrogen peroxide $\left(\mathrm{H}_{2} \mathrm{O}_{2}\right)$ concentration was measured by the method of Fujimoto. ${ }^{5}$ A mixture of D-glucosamine and $\mathrm{Cu}^{2+}$ was incubated at $37^{\circ} \mathrm{C}$ in $50 \mathrm{~mm}$ Tris$\mathrm{HCl}$ buffer ( $\mathrm{pH} 7.2)$ with shaking. At intervals, $0.7 \mathrm{ml}$ of this solution was mixed with $2.8 \mathrm{ml}$ of $1 \%$ titanium sulfate in $2.5 \mathrm{~N} \mathrm{H}_{2} \mathrm{SO}_{4}$ and the $\mathrm{OD}$ at $410 \mathrm{~nm}$ was measured. The amounts of $\mathrm{H}_{2} \mathrm{O}_{2}(\mathrm{~mm})$ were then calculated from a standard calibration curve for $\mathrm{H}_{2} \mathrm{O}_{2}$.

The hydroxyl radical $(\cdot \mathrm{OH})$ concentration was mea-

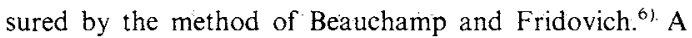
mixture of D-glucosamine and $\mathrm{Cu}^{2+}$ was incubated with $1 \mathrm{mM} 3$-[methylthio]propionaldehyde at $37^{\circ} \mathrm{C}$ in $50 \mathrm{~mm}$ Tris-HCl buffer ( $\mathrm{pH}$ 7.2) in an Erlenmeyer flask sealed with a serum cap and shaken. At intervals, $1 \mathrm{ml}$ of the gas phase above the mixture was analyzed for ethylene on a Yanako G1800 gas chromatograph equipped with a glass column of Chromosorb 102 and a flame ionization detector using $\mathrm{N}_{2}$ as the carrier gas. The amounts of ethylene (ppm) were calculated from the peak area at the retention time of 43 $\mathrm{sec}$ on the chromatogram using a standard calibration curve for ethylene.
Measurement of $\mathrm{Cu}$. Cu was measured using a Hitachi 180-50 atomic absorption spectrophotometer.

\section{Results}

Effects of $\mathrm{Cu}^{2+}$ on the strand breakage of cccDNA by D-glucosamine

Figure 1 shows the course of the reaction of pBR322 ccc-DNA with.0.1 $\mathrm{M}$ D-glucosamine in the presence or absence of $1 \mathrm{mM} \mathrm{Cu}^{2+}$. In the control condition, without $\mathrm{Cu}^{2+}$, the amount of ccc-DNA decreased linearly and slowly with time, and the equivalent amount of oc-DNA appeared. No linear DNA appeared, even after $6 \mathrm{hr}$ of incubation. However, in the presence of $\mathrm{Cu}^{2+}$, all the ccc-DNA was converted into linear DNA via oc-DNA, and, after a prolonged reaction, the resultant linear DNA was further fragmented. Cupric chloride alone at this concentration did not affect the reaction. These results indicate that the Dglucosamine was primarily responsible for the single-strand breakage in the ccc-DNA, and

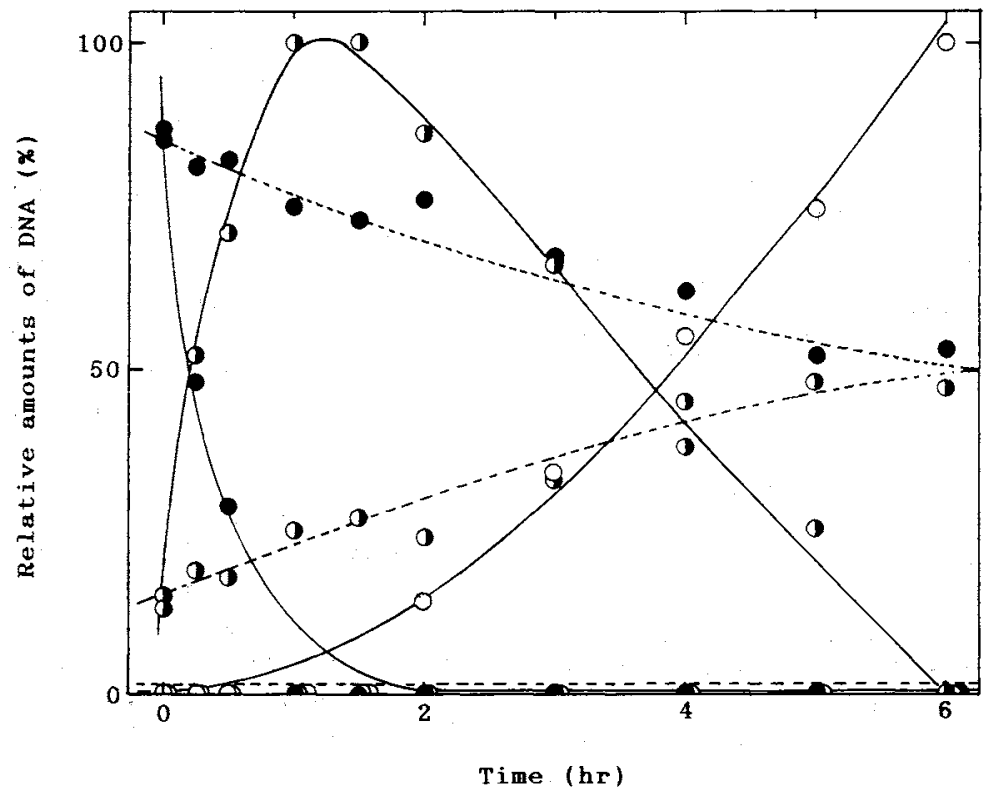

Fig. 1. Course of the Strand Breakage of pBR322 ccc-DNA by D-Glucosamine.

pBR322 ccc-DNA was incubated with $0.1 \mathrm{M}$ D-glucosamine at $37^{\circ} \mathrm{C}$ in $50 \mathrm{~mm}$ Tris- $\mathrm{HCl}$ buffer (pH 7.2) with (-) or without (--) $1 \mathrm{mM} \mathrm{CuCl}_{2}$. At intervals, the amounts of ccc-DNA, oc-DNA, and linear DNA separated from each other by agarose gel electrophoresis were measured.

Symbols: ccc-DNA; 1 , oc-DNA; 0 , linear DNA. 
that this reaction was stimulated by $\mathrm{Cu}^{2+}$. The DNA strand breakage-stimulating activity of $\mathrm{Cu}^{2+}$ was maximum at the concentration of $1 \mathrm{~mm}$, and, at higher concentrations, its activity decreased.

Effects of $\mathrm{Cu}^{2+}$ on the generation of active oxygens in aqueous solutions of D-glucosamine

The effects of $\mathrm{Cu}^{2+}$ on the generation of active oxygens such as $\mathrm{O}_{2}{ }^{-}, \mathrm{H}_{2} \mathrm{O}_{2}$, and $\cdot \mathrm{OH}$ in the aqueous solution of $\mathrm{D}$-glucosamine with or without DNA was then studied, since $\mathrm{Cu}^{2+}$ is known to catalyze the autoxidation of some reducing compounds to generate these active oxygens in aqueous, oxygen-containing solutions. ${ }^{7{ }^{81}}$ As Table I shows, these three kinds of active oxygens were generated in the aque-

Table I. Effects of $\mathrm{Cu}^{2+}$ ON THE Generation OF $\mathrm{O}_{2}^{-}, \mathrm{H}_{2} \mathrm{O}_{2}$, AND $\cdot \mathrm{OH}$ in an Aqueous Solution OF D-GLUCOSAMINE

$\mathrm{O}_{2}^{-}, \mathrm{H}_{2} \mathrm{O}_{2}$, and $\cdot \mathrm{OH}$ generated in the $\mathrm{Cu}^{2+}$-containing aqueous solution of $0.2 \mathrm{M}$ D-glucosamine with or without DNA were measured by the methods described in Materials and Methods. In parentheses are shown their relative amounts to that without $\mathrm{Cu}^{2+}$ and DNA.

\begin{tabular}{|c|c|c|c|c|}
\hline \multirow{3}{*}{$\begin{array}{l}\text { Active } \\
\text { oxygens }\end{array}$} & \multirow{3}{*}{$\begin{array}{l}\text { Concn. } \\
\text { of } \mathrm{Cu}^{2+} \\
(\mathrm{mm})\end{array}$} & \multicolumn{3}{|c|}{ Amounts generated } \\
\hline & & \multicolumn{3}{|c|}{ DNA $(\mu \mathrm{g} / \mathrm{ml})$} \\
\hline & & 0 & 10 & 100 \\
\hline \multirow{6}{*}{$\begin{array}{c}\mathrm{O}_{2}^{-} \\
\left(\Delta \mathrm{OD}_{560 \mathrm{~nm}} /\right. \\
\min \times 100)\end{array}$} & 0 & $0.37(1.0)$ & $0.29(0.8)$ & $0.28(0.8)$ \\
\hline & 0.001 & $0.51(1.4)$ & $0.33(0.9)$ & $0.43(1.2)$ \\
\hline & 0.01 & $0.80(2.2)$ & $0.35(1.0)$ & $0.44(1.2)$ \\
\hline & 0.1 & $0.00(0.0)$ & $0.00(0.0)$ & $0.00(0.0)$ \\
\hline & 1 & $0.00(0.0)$ & $0.00(0.0)$ & $0.00(0.0)$ \\
\hline & 10 & $0.00(0.0)$ & $0.00(0.0)$ & $0.00(0.0)$ \\
\hline \multirow{6}{*}{$\begin{array}{l}\mathrm{H}_{2} \mathrm{O}_{2} \\
(\mathrm{mM})\end{array}$} & 0 & $0.97(1.0)$ & $0.84(0.9)$ & $0.65(0.7)$ \\
\hline & 0.001 & $1.06(1.1)$ & $1.00(1.0)$ & $0.87(0.9)$ \\
\hline & 0.01 & $0.81(0.8)$ & $0.69(0.7)$ & $0.37(0.4)$ \\
\hline & 0.1 & $0.21(0.2)$ & $0.17(0.2)$ & $0.02(0.0)$ \\
\hline & 1 & $0.08(0.0)$ & $0.07(0.0)$ & $0.00(0.0)$ \\
\hline & 10 & $0.08(0.0)$ & $0.08(0.0)$ & $0.00(0.0)$ \\
\hline \multirow{6}{*}{$\begin{array}{l}\cdot \mathrm{OH} \\
(\mathrm{ppm})\end{array}$} & 0 & $13(1.0)$ & $11(0.9)$ & $14(1.1)$ \\
\hline & 0.001 & $32(2.5)$ & $36(2.8)$ & $53(4.1)$ \\
\hline & 0.01 & $146(11.2)$ & $148(11.4)$ & $176(13.5)$ \\
\hline & 0.1 & $261(20.0)$ & $250(19.2)$ & $280(21.5)$ \\
\hline & 1 & $334(25.7)$ & 307 & $344(26.5)$ \\
\hline & 10 & $285(21.9)$ & $305(23.5)$ & 310 \\
\hline
\end{tabular}

ous solution of D-glucosamine even in the absence of $\mathrm{Cu}^{2+}$. However, the amount of - $\mathrm{OH}$ increased greatly as the concentration of $\mathrm{Cu}^{2+}$ increased, up to $1 \mathrm{~mm}$. At higher concentrations of $\mathrm{Cu}^{2+}$, the amounts of $\cdot \mathrm{OH}$ generated decreased. On the other hand, the concentrations of $\mathrm{Cu}^{2+}$ that yielded the maximal amounts of $\mathrm{O}_{2}^{-}$and $\mathrm{H}_{2} \mathrm{O}_{2}$ were 0.01 and $0.001 \mathrm{~mm}$, respectively. The amounts of these active oxygens generated, however, were only a little higher than those generated in the absence of $\mathrm{Cu}^{2+}$. At $1 \mathrm{~mm} \mathrm{Cu}{ }^{2+}$, little of either $\mathrm{O}_{2}{ }^{-}$or $\mathrm{H}_{2} \mathrm{O}_{2}$ could be detected. The concentration of $\mathrm{Cu}^{2+}$ which yielded the maximal amounts of $\cdot \mathrm{OH}$ matched the $\mathrm{Cu}^{2+}$ concentration needed to stimulate the D-glucosamine-induced strand-breakage of DNA (see Table II). The generation of these active oxygens, either in the presence or absence of $\mathrm{Cu}^{2+}$, was not affected much by the addition of DNA. The apparent, slight decrease in the case of $\mathrm{H}_{2} \mathrm{O}_{2}$ was found to be due to a preventative effect of DNA on the reaction between $\mathrm{H}_{2} \mathrm{O}_{2}$ and $\mathrm{TiSO}_{4}$ (data not presented in this paper).

Effects of enzymes and radical scavengers on the D-glucosamine-induced DNA strandbreakage in the presence of $\mathrm{Cu}^{2+}$

Table III shows the effects of some en-

Table II. EfFects of $\mathrm{Cu}^{2+}$ ON THE STRAND BREAKAGE OF PBR322 ccc-DNA BY D-GLuCOSAMine

Plasmid pBR322 ccc-DNA was incubated with $0.2 \mathrm{M} \mathrm{D}-$ glucosamine at $37^{\circ} \mathrm{C}$ for $3 \mathrm{hr}$ in $50 \mathrm{~mm}$ Tris $-\mathrm{HCl}$ buffer $(\mathrm{pH} \mathrm{7.2)}$ in the presence of the indicated concentrations of $\mathrm{CuCl}_{2}$.

\begin{tabular}{cccc}
\hline \multirow{2}{*}{$\mathrm{CuCl}_{2}(\mathrm{mM})$} & \multicolumn{3}{c}{ Relative amounts of DNA $(\%)$} \\
\cline { 2 - 4 } & \multicolumn{2}{c}{ occ- } & linear \\
\hline Control $^{a}$ & 78.6 & 21.4 & 0 \\
\hline 0 & 36.8 & 63.2 & 0 \\
0.1 & 34.3 & 65.7 & 0 \\
1.0 & 0 & 71.3 & 28.7 \\
10.0 & 0 & 90.8 & 9.2 \\
\hline
\end{tabular}

a pBR322 ccc-DNA was incubated neither with $\mathrm{CuCl}_{2}$ nor D-glucosamine. 
Table III. Effects of EnZymes on the Strand BREAKAGE OF pBR322 ccc-DNA BY D-GLuCOSAMINE

pBR322 ccc-DNA $(1 \mu \mathrm{g})$ was incubated with $0.1 \mathrm{M}$ D-glucosamine at $37^{\circ} \mathrm{C}$ in $50 \mathrm{~mm}$ Tris- $\mathrm{HCl}$ buffer $(\mathrm{pH}$ 7.2) in the presence of enzymes for $3 \mathrm{hr}$ with or without $1 \mathrm{~mm} \mathrm{CuCl} 2$. Percent inhibition of the DNA strand breakage was computed from the amounts of ccc-DNA and linear DNA as follows: Inhibition $(\%)=$ $\left\{\left[\left(C_{\mathrm{I}}-L_{\mathrm{I}}\right)-(C-L)\right]\right\} /\left\{\left[C_{\mathrm{O}}-(C-L)\right]\right\} \times 100$, where $C_{\mathrm{I}}$ and $L_{1}$ are the amounts of remaining ccc-DNA and linear-DNA of the system with inhibitor, $C$ and $L$ those of a control system without inhibitor, and $C_{O}$ is that of remaining ccc-DNA of an another control system with neither inhibitor nor D-glucosamine. In parentheses are shown the data with their respective enzymes which were boiled previously for $10 \mathrm{~min}$

\begin{tabular}{lccc}
\hline & Concn. & \multicolumn{2}{c}{ Inhibition $(\%)$} \\
\cline { 3 - 5 } Enzymes & $(\mu \mathrm{g} / \mathrm{ml})$ & $\mathrm{Cu}^{2+}(-)$ & $\mathrm{Cu}^{2+}(+)$ \\
\hline SOD $^{a}$ & 0.1 & $14(-3)$ & $-1(2)$ \\
& 1.0 & $41(10)$ & $0(1)$ \\
& 10 & $49(10)$ & $0(0)$ \\
Catalase & 100 & $52(33)$ & $0(1)$ \\
& 0.1 & $13(-39)$ & $2(-1)$ \\
& 1.0 & $18(-4)$ & $1(-1)$ \\
SOD & 10 & $91(-31)$ & $31(2)$ \\
& 100 & $98(-39)$ & $80(1)$ \\
& 0.1 & $15(2)$ & $2(2)$ \\
& 1.0 & $56(2)$ & $1(1)$ \\
& 10 & $94(26)$ & $34(0)$ \\
& 100 & $94(24)$ & $82(3)$ \\
\hline
\end{tabular}

a Superoxide dismutase.

zymes on the D-glucosamine-induced DNA strand-breakage either in the presence or absence of $1 \mathrm{mM} \mathrm{Cu}{ }^{2+}$. Superoxide dismutase, which causes disproportionation in $\mathrm{O}_{2}{ }^{-}$to yield $\mathrm{H}_{2} \mathrm{O}_{2}$, weakly inhibited the reaction in the absence of $\mathrm{Cu}^{2+}$ However, inhibition of the reaction by the heat-inactivated superoxide dismutase demonstrated a nonspecific inhibitory action of the enzyme protein on the inhibitory effect of superoxide dismutase. On the other hand, in the presence of $\mathrm{Cu}^{2+}$, superoxide dismutase did not affect the strandbreaking reaction. Catalase inhibited the reaction even in the presence of $\mathrm{Cu}^{2+}$, although its inhibitory effect was somewhat weaker than that in the absence of $\mathrm{Cu}^{2+}$. The activity of catalase and superoxide dismutase, together,
Table IV. EFFects of Radical SCAVEngERs on THE STRAND BREAKage OF pBR322 ccc-DNA BY D-GLUCOSAMINE

pBR322 ccc-DNA $(1 \mu \mathrm{g})$ was incubated with $0.1 \mathrm{M} \mathrm{D}-$ glucosamine at $37^{\circ} \mathrm{C}$ in $50 \mathrm{~mm}$ Tris- $\mathrm{HCl}$ buffer $(\mathrm{pH} 7.2)$ in the presence of radical scavengers for $3 \mathrm{hr}$ with or without $1 \mathrm{mM} \mathrm{CuCl}$. Percent inhibition of the DNA strand breakage was computed as shown in the footnote of Table III. Corresponding active oxygens are shown in parentheses.

\begin{tabular}{|c|c|c|c|}
\hline \multirow{2}{*}{ Additions } & \multirow{2}{*}{$\begin{array}{c}\text { Concn. } \\
(\mathrm{mm})\end{array}$} & \multicolumn{2}{|c|}{ Inhibition $(\%)$} \\
\hline & & $\mathrm{Cu}^{2+}(-)$ & $\mathrm{Cu}^{2+}(+)$ \\
\hline \multirow[t]{4}{*}{$\operatorname{Tiron}^{a}\left(\mathrm{O}_{2}^{-}\right)$} & 0.1 & 4 & 0 \\
\hline & 1.0 & 70 & 0 \\
\hline & 10 & 104 & 1 \\
\hline & 100 & - & 96 \\
\hline \multirow[t]{3}{*}{$\mathrm{KI}(\cdot \mathrm{OH})$} & 1.0 & 8 & 0 \\
\hline & 10 & 22 & 16 \\
\hline & 100 & 58 & 48 \\
\hline \multirow[t]{3}{*}{ Thiourea $(\cdot \mathrm{OH})$} & 1.0 & 0 & 15 \\
\hline & 10 & 10 & 39 \\
\hline & 100 & 83 & 94 \\
\hline \multirow[t]{3}{*}{ HCOONa $(\cdot \mathrm{OH})$} & 1.0 & 0 & 8 \\
\hline & 10 & 8 & 9 \\
\hline & 100 & 29 & 28 \\
\hline \multirow[t]{3}{*}{ D-Mannitol $(\cdot \mathrm{OH})$} & 1.0 & 9 & 10 \\
\hline & 10 & 13 & 12 \\
\hline & 100 & 30 & 17 \\
\hline \multirow[t]{3}{*}{$\mathrm{DMSO}^{b}(\cdot \mathrm{OH})$} & 1.0 & 1 & 0 \\
\hline & 10 & 13 & 6 \\
\hline & 100 & 66 & 16 \\
\hline \multirow[t]{3}{*}{$\mathrm{DABCO} \mathrm{O}^{c}\left({ }^{1} \mathrm{O}_{2}\right)$} & 1.0 & -27 & 4 \\
\hline & 10 & -46 & -7 \\
\hline & 100 & -59 & -27 \\
\hline
\end{tabular}

4,5-Dihydroxy-1,3-benzendisulfonic acid.

$b$ Dimethyl sulfoxide.

c 1,4-Diazabicyclo[2.2.2]octane.

was not more than the activity of catalase alone. As Table IV shows, among the radical scavengers, Tiron, which scavenges $\mathrm{O}_{2}{ }^{-}$, inhibited the reaction most effectively; its inhibition of the reaction was more effective in the absence than in the presence of $\mathrm{Cu}^{2+}$. This may have been due to a possible chelating action of Tiron on metal ions. ${ }^{9)}$ Some hydroxyl radical-scavengers, such as $\mathrm{KI}$, thiourea, HCOONa, D-mannitol, and dimethyl sulfoxide, inhibited the reaction in the pres- 


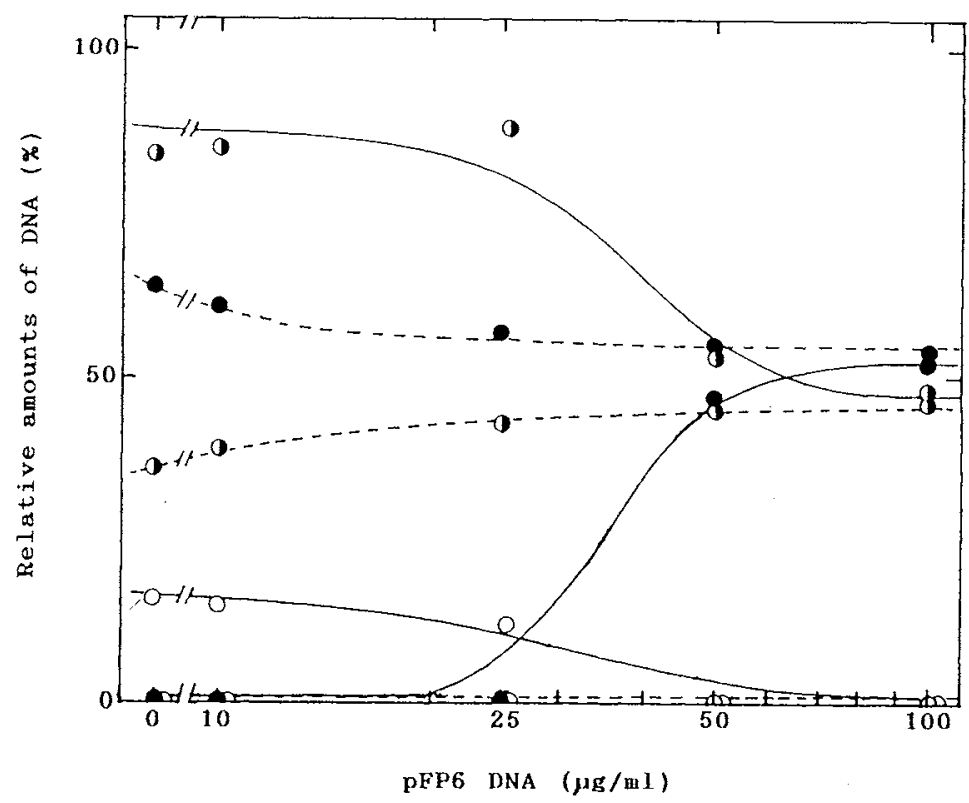

Fig. 2. Effects of pFP6 DNA on the Strand Breakage of Plasmid pBR322 ccc-DNA by D-Glucosamine. pBR322 ccc-DNA $(0.1 \mu \mathrm{g})$ was incubated with $0.1 \mathrm{M} \mathrm{D}$-glucosamine at $37^{\circ} \mathrm{C}$ in $50 \mathrm{~mm}$ Tris- $\mathrm{HCl}$ buffer $(\mathrm{pH} 7.2)$ in the presence of various concentrations of pFP6 DNA for $3 \mathrm{hr}$ with (-) or without (--) $1 \mu \mathrm{M} \mathrm{CuCl}_{2}$. Symbols: , ccc-DNA; 1 , oc-DNA; $O$, linear DNA.

ence as well as the absence of $\mathrm{Cu}^{2+}$. DABCO, an ${ }^{1} \mathrm{O}_{2}$ quencher, accelerated the reaction, although the reason for this effect remains unclear. These results suggest that $\mathrm{Cu}^{2+}$ may change $\mathrm{O}_{2}{ }^{-}$, which is generated at the first stage of autoxidation of D-glucosamine in the $\mathrm{O}_{2}$-containing aqueous solution, into . $\mathrm{OH}$ via $\mathrm{H}_{2} \mathrm{O}_{2}$, and that $\mathrm{OH}$ is finally responsible for the DNA strand-breakage. In addition to undergoing disproportionation, $\mathrm{O}_{2}{ }^{-}$is also known to react with $\mathrm{H}_{2} \mathrm{O}_{2}$ to give $\cdot \mathrm{OH}^{20)}$

\section{Binding of $\mathrm{Cu}^{2+}$ to DNA}

The effects of pFP6 linear DNA, which is distinguishable from ccc, oc- and linear DNA of pBR322 by agarose gel electrophoresis, on D-glucosamine-induced DNA strand-breakage in the presence of $\mathrm{Cu}^{2+}$ was then examined. As Fig. 2 shows, the reaction was inhibited by adding pFP6 linear DNA in a concentrationdependent manner. In the absence of $\mathrm{Cu}^{2+}$, however, the reaction was not affected by the increasing concentration of added pFP6 linear

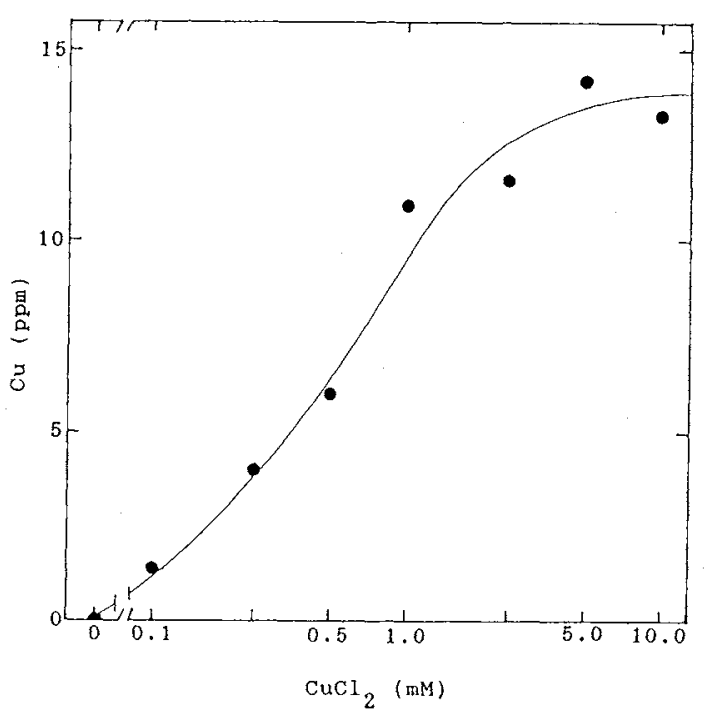

Fig. 3. Binding of $\mathrm{Cu}^{2+}$ to pBR322 ccc-DNA.

pBR322 ccc-DNA $(100 \mu \mathrm{g})$ was incubated with various concentrations of $\mathrm{CuCl}_{2}$ at $37^{\circ} \mathrm{C}$ in $10 \mathrm{~mm}$ Tris- $\mathrm{HCl}$ buffer (pH 8.0 ) for $3 \mathrm{hr}$, and the mixture $(1 \mathrm{ml})$ were dialysed against $1000 \mathrm{ml}$ of the same buffer overnight at $4^{\circ} \mathrm{C}$ with 3 changes of buffer to remove free $\mathrm{CuCl}_{2}$. The amounts of $\mathrm{Cu}$ bound to ccc-DNA were measured by atomic absorption analysis. $1 \mathrm{mM}=63.54 \mathrm{ppm}$. 
Table V. EFFECTS OF DEOXYRIBONUCLEOTIDE ON THE Strand Breakage of PBR322 ccc-DNA BY D-GLUCOSAMINE

pBR322 ccc-DNA was incubated with $0.1 \mathrm{M}$ Dglucosamine at $37^{\circ} \mathrm{C}$ in $50 \mathrm{~mm}$ Tris- $\mathrm{HCl}$ buffer $(\mathrm{pH} 7.2)$ in the presence of each deoxyribonucleotide for $3 \mathrm{hr}$ with or without $1 \mathrm{~mm} \mathrm{CuCl} \mathrm{Cl}_{2}$. Percent inhibition of the DNA strand breakage by each addition was the same as that in the footnote of Table III.

\begin{tabular}{|c|c|c|c|}
\hline \multirow{2}{*}{ Additions } & \multirow{2}{*}{$\begin{array}{c}\text { Concn. } \\
(\mathrm{mm})\end{array}$} & \multicolumn{2}{|c|}{ Inhibition $(\%)$} \\
\hline & & $\mathrm{Cu}^{2+}(-)$ & $\mathrm{Cu}^{2+}(+)$ \\
\hline None & - & 0 & 0 \\
\hline \multirow[t]{4}{*}{ d-GMP } & 1 & -16 & 0 \\
\hline & 10 & -50 & 9 \\
\hline & 50 & -69 & 20 \\
\hline & 100 & -73 & 28 \\
\hline \multirow[t]{2}{*}{ d-AMP } & 1 & -10 & -12 \\
\hline & 100 & -51 & 14 \\
\hline \multirow[t]{2}{*}{ d-CMP } & 1 & -17 & 0 \\
\hline & 100 & -66 & -2 \\
\hline \multirow[t]{2}{*}{$\mathrm{d}-\mathrm{TMP}$} & I & -10 & -3 \\
\hline & 100 & -75 & 0 \\
\hline
\end{tabular}

DNA. These results suggest that $\mathrm{Cu}^{2+}$ may bind to DNA. To confirm that binding of $\mathrm{Cu}^{2+}$ to pBR322 ccc-DNA occurred, the bound $\mathrm{Cu}^{2+}$ was measured by atomic absorption analysis. After incubating the DNA with various concentrations of $\mathrm{Cu}^{2+}$, the mixtures were dialysed to remove free $\mathrm{Cu}^{2+}$, and the $\mathrm{Cu}$ in the inner dialysate was measured. As Fig. 3 shows, the amounts of $\mathrm{Cu}$ increased in a concentration-dependent manner, confirming that $\mathrm{Cu}^{2+}$ was bound to the DNA. It was also shown that these $\mathrm{Cu}^{2.4}$-treated DNAs were broken by $\mathrm{D}$-glucosamine much more readily than untreated DNA (data not shown here).

To identify the sites on ccc-DNA at which $\mathrm{Cu}^{2+}$ preferentially binds, the effects of some deoxyribonucleotides on the DNA strand breakage by D-glucosamine was examined. As Table $\mathrm{V}$ shows, in the absence of $\mathrm{Cu}^{2+}$, the reaction was stimulated by all the deoxyribonucleotides tested. Deoxyriboses did not affect the reaction in the presence or absence of $\mathrm{Cu}^{2+}$, but phosphate stimulated the reaction (data not presented in this paper). These re- sults suggest that the stimulating effects of deoxyribonucleotides in the absence of $\mathrm{Cu}^{2+}$ may be due to their phosphate groups. On the other hand, in the presence of $\mathrm{Cu}^{2+}$, d-GMP inhibited the reaction to some extent, but the other deoxyribonucleotides hardly affected the reaction. Therefore, the binding sites of $\mathrm{Cu}^{2+}$ may be deoxyguanylate regions of the DNA, as has been shown previously by Pezzano and Podo. ${ }^{10)}$

\section{Discussion}

In this study we have confirmed and extended our previous observation that the stimulating effect of $\mathrm{Cu}^{2+}$ on the D-glucosamineinduced pBR322 ccc-DNA strand breakage is due mainly to its stimulating effect on the generation of a series of active oxygen molecules, especially $\mathrm{OH}$, in the aqueous solution of D-glucosamine. This kind of mechanism, suggested here for $\mathrm{Cu}^{2+}$, is essentially similar to those reported already for Lascorbic acid, ${ }^{11}$ triose reductone, ${ }^{11}$ mitomy$\operatorname{cin} \mathrm{C}^{12)} \mathrm{D}$-isoglucosamine, ${ }^{13)}$ and D-fructose6-phosphate. ${ }^{14\}}$ The optimum concentration of $\mathrm{Cu}^{2+}$ (approximately $1 \mathrm{~mm}$ ) for stimulation of $\mathrm{OH}$ generation in the aqueous solution of D-glucosamine was the same as that for stimulation of the D-glucosamine-induced DNA strand breakage. At this $\mathrm{Cu}^{2+}$ concentration, the amounts of both $\mathrm{O}_{2}{ }^{-}$and $\mathrm{H}_{2} \mathrm{O}_{2}$ generated in D-glucosamine solutions were almost negligible. From our results and a proposed mechanism of the production of active oxygens, ${ }^{19.20)} \mathrm{O}_{2}{ }^{-}$and $\mathrm{H}_{2} \mathrm{O}_{2}$ are considered to be the intermediates, and $\cdot \mathrm{OH}$ is the active molecule involved in the DNA strand breakage. At $\mathrm{Cu}^{2+}$ concentrations higher than $1 \mathrm{~mm}, \cdot \mathrm{OH}$ may be changed to stable molecules that are less reactive with the DNA.

The possibility of involvement of the other active oxygens, such as ${ }^{1} \mathrm{O}_{2}$ and $\mathrm{HO}_{2} \cdot$, in the reaction may be neglected, although their concentrations were not measured in these experiments. Merkel and Kearns ${ }^{15}$ ) have shown that ${ }^{1} \mathrm{O}_{2}$ has an extremely short length of life in aqueous solution. Kobayashi ${ }^{16\}}$ has shown 
that the concentrations of $\mathrm{HO}_{2} \cdot$ recognized in aqueous solution of $\mathrm{pH} 7-8$ are $1 / 100-1 / 1000$ as much as that of $\mathrm{O}_{2}{ }^{-}$. The possible production of glucosamine radicals, which may take part in the DNA strand breakage in the aqueous solution of D-glucosamine, is a subject for further investigation.

$\mathrm{Cu}^{2+}$ was found to bind to the ccc-DNA of pBR322 by measuring the bound $\mathrm{Cu}$ by atomic absorption analysis. Eichhorn et al. ${ }^{17.18)}$ have shown that, besides $\mathrm{Cu}^{2+}$, many divalent cations such as $\mathrm{Mg}^{2+}, \mathrm{Mn}^{2+}, \mathrm{Zn}^{2+}, \mathrm{Ni}^{2+}, \mathrm{Co}^{2+}$ and $\mathrm{Hg}^{2+}$ can be bound to phosphate groups of DNA, and thereby change the conformation of the helical structure of DNA. However, these divalent cations do not affect the Dglucosamine-induced DNA strand breakage. This may be because the stimulating effects of these divalent cations on the generation of active oxygens in the aqueous solution of $\mathrm{D}$ glucosamine are much less than those of $\mathrm{Cu}^{2+}$.

The D-glucosamine-induced pBR322 cccDNA strand breakage in the presence of $\mathrm{Cu}^{2+}$ was inhibited by the addition of a different (pFP6 linear) DNA, but the generation of . $\mathrm{OH}$ from the aqueous solution of Dglucosamine was not. These results demonstrate that $\mathrm{Cu}^{2+} \mathrm{s}$ function in the autoxidation of D-glucosamine is attributable to the $\mathrm{Cu}^{2+}$-DNA complex produced, as has been suggested, also, by Shinohara et al., ${ }^{11)}$ using $\mathrm{L}$-ascorbic acid and triose reductone. The produced $\mathrm{Cu}^{2+}$-DNA complex may oxidize $D$-glucosamine in the vicinities to generate - $\mathrm{OH}$, which is finally responsible for the DNA strand breakage. The inhibition of the Dglucosamine-induced DNA strand breakage in the presence of $\mathrm{Cu}^{2+}$ by the addition of a different DNA, therefore, might be due to competitive binding of $\mathrm{Cu}^{2+}$ to the added DNA; this would decrease the amount of $\mathrm{Cu}^{2+}$ available to bind to the target pBR322 DNA. The reason why the generation of $\cdot \mathrm{OH}$ from the aqueous solution of $\mathrm{D}-$ glucosamine was not affected by the addition of the DNA may be that D-glucosamine can be oxidized to the same extent either by $\mathrm{Cu}^{2+}$ DNA complex or $\mathrm{Cu}^{2+}$. Besides $\mathrm{Cu}^{2+}$-DNA complex, however, we can not exclude the possibility of the formation of $\mathrm{Cu}^{2+}$-D-glucosamine or DNA-Cu ${ }^{2+}$-D-glucosamine complexes. These will be the subjects of later investigation.

The facts that D-glucosamine-induced DNA strand breakage in the presence of $\mathrm{Cu}^{2+}$ was inhibited only by d-GMP among the deoxyribonucleotides tested and that the generation of $\cdot \mathrm{OH}$ from the aqueous solution of $\mathrm{D}$ glucosamine in the presence of $\mathrm{Cu}^{2+}$ was not inhibited by d-GMP (data not presented in this paper) indicate that $\mathrm{d}-\mathrm{GMP}-\mathrm{Cu}^{2+}$ complexes will take part in the $\mathrm{OH}$-generation from aqueous solution of D-glucosamine as DNA$\mathrm{Cu}^{2+}$ complex dose. Deoxyguanilate regions of the DNA may be possible binding sites for $\mathrm{Cu}^{2+}$ and/or preferred DNA damage sites. The nucleotide sequences in DNA subject to strand breakage induced by D-glucosamine in the presence of $\mathrm{Cu}^{2+}$ are currently being investigated.

Acknowledgments. We thank the following students of Fukuoka University for their technical assistance in some experiments: Hirotoshi Fukumitsu, Kikuo Nishizumi, Masahide Oh-ishi, Yunan Oh-shige, Yuki Kusuhara and Kazuko Hidaka.

\section{References}

1) K. Watanabe, T. Sasaki, N. Kashige, K. Ishibashi, Y. Nakashima and M. Hayashida, Agric. Biol. Chem., 49, 63 (1985).

2) K. Watanabe, N. Kashige, Y. Nakashima, M. Hayashida and K. Sumoto, Agric. Biol. Chem., 50, 1459 (1986).

3) Y. M. Kupersztoch-Portony, M. A. Lovett and D. R. Helinski, Biochem., 13, 5484 (1974).

4) C. Beauchamp and I. Fridovich, Anal. Biochem., 44, 276 (1971).

5) S. Fujimoto, Cancer Res., 25, 534 (1965).

6) C. Beauchamp and I. Fridovich, J. Biol. Chem., 245, 4641 (1970).

7) E. S. G. Barron, Z. B. Miller and G. Kalnitsky, Biochem. J., 41, 62 (1974).

8) Y. Kono, Arch. Biochem. Biophys., 186, 189 (1978).

9) R. W. Miller and U. Rapp, J. Biol. Chem., 248, 6084 (1973).

10) H. Pezzano and F. Podo, Chem. Rev, 80, 365 (1980).

11) K. Shinohara, M. So, M. Nonaka, K. Nishiyama, H. Murakami and H. Omura, J. Nutr. Sci. Vitaminol, 
29, 489 (1983).

12) K. Ueda, J. Morita and T. Komano, J. Antibiot., 34, 317 (1981).

13) S. Nanjou, S. Fujii, K. Tanaka, K. Ueda and T. Komano, Agric. Biol. Chem., 49, 459 (1985).

14) J. Morita and T. Komano, Agric. Biol. Chem., 47, 11 (1983).

15) P. B. Merkel and D. R. Kearns, J. Am. Chem. Soc.. 94, 7244 (1972).

16) K. Kobayashi, Tanpakushitsu Kakusan Kohso, 33. 2678 (1988).
17) G. L. Eichhorn and Y. A. Shin, J. Am. Chem. Soc., 90, 7323 (1986).

18) G. L. Eichhorn and P. Clark, Proc. Natl. Acad. Sci., U.S.A., 53, 586 (1965).

19) W. A. Pryor, "Free Radicals in Biology," Vol. I, ed. by W. A. Pryor, Academic Press, New York, 1976, pp. $1-49$.

20) I. Fridovich, "Free Radicals in Biology," Vol. I, ed. by W. A. Pryor, Academic Press, New York, 1976. pp. 239- 277. 